\title{
Influence of Rainwater Infiltration in Partial Anti-Seepage Bioretention on Adjacent Municipal Roads in Different Collapsible Grades Loess Sites
}

\author{
Xin Wen ${ }^{D}$, Zhiping $\mathrm{Hu}^{*}$, Yanlin Jing, Xiaole Li, Xun Zhang and Shaobo Chai \\ School of Civil Engineering, Chang'an University, Xi'an 710061, China; wenxin@chd.edu.cn (X.W.); \\ yanlinjing86@163.com (Y.J.); 2015128081@chd.edu.cn (X.L.); xunzhang@chd.edu.cn (X.Z.); \\ shbchai@chd.edu.cn (S.C.) \\ * Correspondence: huzhping@chd.edu.cn; Tel.: +86-29-82337356
}

check for updates

Citation: Wen, X.; Hu, Z.; Jing, Y.; Li, X.; Zhang, X.; Chai, S. Influence of Rainwater Infiltration in Partial Anti-Seepage Bioretention on Adjacent Municipal Roads in Different Collapsible Grades Loess Sites. Water 2021, 13, 2055. https:// doi.org/10.3390/w13152055

Academic Editor: Fernando António Leal Pacheco

Received: 13 May 2021

Accepted: 26 July 2021

Published: 28 July 2021

Publisher's Note: MDPI stays neutral with regard to jurisdictional claims in published maps and institutional affiliations.

Copyright: (c) 2021 by the authors. Licensee MDPI, Basel, Switzerland. This article is an open access article distributed under the terms and conditions of the Creative Commons Attribution (CC BY) license (https:/ / creativecommons.org/licenses/by/ $4.0 /)$.

\begin{abstract}
It is practical to carry out sponge cities to manage rain and floods in collapsible loess areas where water resources and water disasters are prominent. The infiltration laws of the partial anti-seepage bioretention in collapsible loess fields are helpful to ensure the effectiveness and safety of sponge city, which were learned from the field test and numerical model. The seepage field and displacement field of loess sites with different collapsibility grades were compared during rainwater infiltration of the bioretention with the numerical model; the suitability and optimization suggestions for foundation treatment of this structure in various sites were proposed. It is found that the infiltration characteristics can be divided into three stages, and the infiltration range of bioretention increases with increasing infiltration time under the same site type, and the higher the collapsibility level of the site is, the more significant the rise in infiltration range. The settlement of adjacent roads in class II and III collapsible fields is far greater than that in class I and is greater than the settlement standard. The facilities' bottom part foundation can be replaced to ensure the functionality of the facilities and the safety of the surrounding roads in the actual project.
\end{abstract}

Keywords: bioretention; infiltration risk; infiltration range; road settlement; collapsible loess

\section{Introduction}

In recent years, sponge cities based on low-impact development facilities have become an effective means of urban stormwater control, water resource management, and landscape improvement [1-5], which has led to sponge cities being popularized and constructed in the central and western regions of China (Figure 1). This measure can solve the urban waterlogging phenomenon caused by frequent extreme weather, alleviate the problem of water resource shortages, such as the evaporation of rainwater being far more significant than its rainfall, and actively improve the urban living environment [6]. As a kind of subtable unsaturated soil widely distributed globally, loess easily collapses when it meets water, and loess collapsibility often leads to engineering geological disasters, such as house tilt and road collapse [7-10]. Therefore, at collapsible loess sites, when building sponge cities, there are some problems, such as the realization of sponge facility functions, including increased rainwater retention time on the underlying surface, increased total infiltration, and centralized infiltration of surface runoff, which are contradictory to the maintenance of water environment stability in the prevention and control of loess disasters. Based on the collapsible loess site, the influence of rainwater infiltration of sponge facilities and the optimization of facilities play a positive role in solving the above problems.

As an important part of sponge cities, bioretention is mainly arranged around municipal roads and buildings. At present, research on facilities primarily focuses on runoff reduction, non-point source pollution purification, and facility combination management $[4,11-16]$. Results show that bioretention facilities can significantly reduce the surface 
runoff, and the regulation effect of facilities on rainfall-runoff is affected by soil matrix conditions, vegetation conditions, rainfall characteristics, and blocking state; additionally, the degree of water purification is affected by vegetation type, flow velocity, adequate water depth, hydraulic retention time, and other factors. On the other hand, many scholars have studied the infiltration law of rainwater in collapsible loess and its influencing factors, as shown in Table 1. Studies show that the existing rainwater infiltration impact assessment in loess areas is mainly carried out from single-layer homogeneous soil and continuous rainfall conditions. For the collapsible loess site, if water diversion and infiltration measures are not taken, water infiltration is limited to no more than $3 \mathrm{~m}$. Additionally, the infiltration characteristics are related to soil parameters, including the initial water content, soil saturation, and permeability coefficient. Under different initial conditions (water head, infiltration time, infiltration mode, and site), the infiltration law of loess is different, and the infiltration depth is greater when rainwater is concentrated. For the bioretention facilities with layered internal structures, the infiltration characteristics of concentrated rainwater are different from those of single-layer homogeneous loess rainfall. Therefore, it is necessary to study the law of water infiltration in bioretention foundations in loess sites.

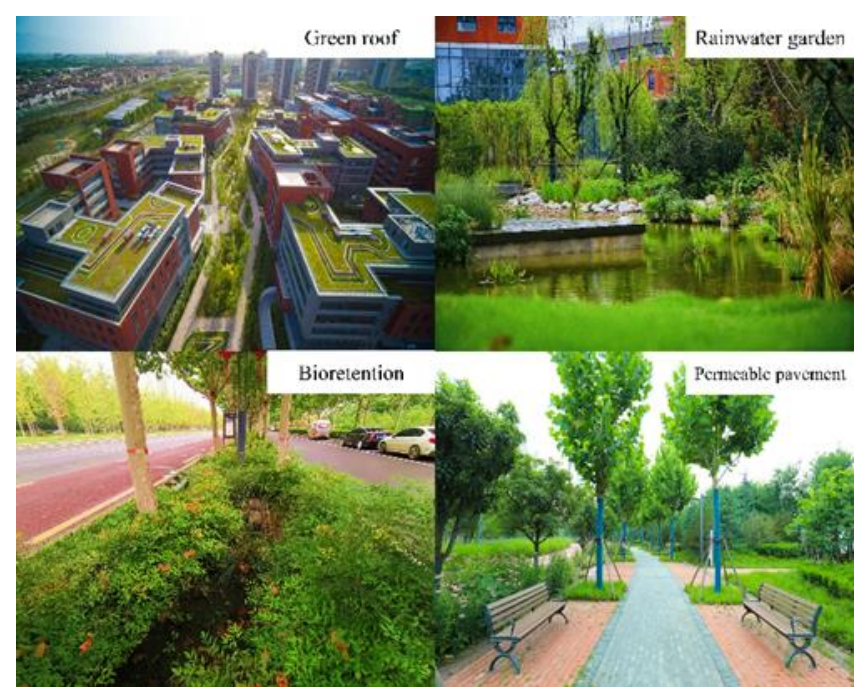

Figure 1. Typical LID facilities in loess area.

Table 1. Summary of research on the loess water infiltration range.

\begin{tabular}{|c|c|c|c|c|}
\hline Author & Site Location & Infiltration Conditions & Test Duration & Infiltration Range \\
\hline Huang et al. [17] & Lanzhou, Gansu & $\begin{array}{l}\text { The diameter of the test pit is } \\
40 \mathrm{~m} \text {, and the height is } 0.5 \mathrm{~m} \\
\text { Ponding height is } 0.3-0.5 \mathrm{~m}\end{array}$ & $140 \mathrm{~h}$ & $\begin{array}{l}\text { The infiltration depth is } \\
\text { between } 20 \mathrm{~m} \text { and } 25 \mathrm{~m}\end{array}$ \\
\hline Wu et al. [18] & Haidong, Qinghai & $\begin{array}{l}\text { The diameter of the test pit is } \\
20 \mathrm{~m} \text {, and the height is } 0.5 \mathrm{~m} \\
\text { The total immersion is } 20 \mathrm{t}\end{array}$ & 89 days & $\begin{array}{l}\text { The influence range of } \\
\text { saturation is } \\
\text { approximately } 6.5 \mathrm{~m} \text {; } \\
\text { The influence range of } \\
\text { unsaturated infiltration } \\
\text { is about } 14 \mathrm{~m}\end{array}$ \\
\hline
\end{tabular}


Table 1. Cont.

\begin{tabular}{|c|c|c|c|c|}
\hline Author & Site Location & Infiltration Conditions & Test Duration & Infiltration Range \\
\hline Tu X.B. et al. [19] & $\begin{array}{c}\text { Beside Expressway in } \\
\text { loess area of Northwest } \\
\text { China }\end{array}$ & $\begin{array}{l}\text { The size of the test site } \\
\text { is } 25 \mathrm{~m} \times 10 \mathrm{~m} \\
\text { The annual average } \\
\text { rainfall is } 600 \mathrm{~mm}\end{array}$ & Two years & $\begin{array}{l}\text { When the maximum } \\
\text { rainfall intensity is } \\
0.04 \mathrm{~m} / \mathrm{d} \text {, the } \\
\text { infiltration and } \\
\text { evaporation activities } \\
\text { of loess are mainly } \\
\text { within } 0.7 \mathrm{~m} \text { below the } \\
\text { surface, and the depth } \\
\text { of wetting front is } \\
\text { approximately } 2 \mathrm{~mm} \text {; } \\
\text { When the rainfall } \\
\text { intensity is } 0.12 \mathrm{~m} / \mathrm{d} \text {, } \\
\text { the depth of the } \\
\text { wetting front is } \\
\text { approximately } 3 \mathrm{~mm}\end{array}$ \\
\hline Zhang et al. [20] & Ganquan, Shaanxi & Natural rainfall & Ten days & $\begin{array}{l}\text { The infiltration depth is } \\
1 \mathrm{~m}\end{array}$ \\
\hline Liu et al. [21] & Fuping, Shaanxi & $\begin{array}{c}\text { The size of the test site } \\
\text { is } 3 \mathrm{~m} \times 8 \mathrm{~m} \\
\text { rainfall intensity is } \\
21.4 \mathrm{~mm} / \mathrm{h} \text {; Rainfall } \\
\text { duration is } 14 \mathrm{~h}\end{array}$ & $\begin{array}{c}\text { The water content is } \\
\text { stable }\end{array}$ & $\begin{array}{l}\text { The infiltration depth is } \\
\text { less than } 2.7 \mathrm{~m} \text {, and the } \\
\text { saturation depth is only } \\
0.2 \mathrm{~m}\end{array}$ \\
\hline Li et al. [22] & Zhengning, Gansu & $\begin{array}{l}\text { The diameter of the } \\
\text { exploratory well is } 1 \mathrm{~m} \text {, } \\
\text { and the depth is } 10 \mathrm{~m} \text {; } \\
\text { Natural rainfall }\end{array}$ & One year & $\begin{array}{c}\text { The infiltration depth is } \\
\text { within } 2 \mathrm{~m} \text { from the } \\
\text { surface }\end{array}$ \\
\hline
\end{tabular}

However, there are few studies on the interaction between rainwater infiltration of bioretention and complex hydrogeological environments, such as collapsible loess sites. Based on facilities' functional and site mechanical characteristics in collapsible loess areas, some scholars have proposed that shallow and small infiltration facilities should be used as much as possible in this area [23]. For bioretention in addition to municipal roads in collapsible loess sites, PE waterproof geotextiles are laid at the bottom for complete protection, and concrete retaining walls are poured on both sides of grass planting ditches to ensure the safety of road subgrades [24]. The above research provides a solution for the safe construction of sponge facilities in collapsible loess. However, based on numerical simulations with four kinds of facility bottom lengths in heterogeneous soil, Andrea found that the complete closure of the facility's bottom has a significant impact on the hydraulic performance of the facility $[25,26]$. Therefore, in the collapsible loess area, it is difficult to ensure the function of sponge facilities by simply using the form of the impervious membrane. Meanwhile, based on the influence law of rainwater infiltration of typical sponge facilities in Xixian New Area on the surrounding municipal roads, Liang et al. [27] obtained the partial anti-seepage bioretention, which is all sides and partially bottom of the facility are paved with impervious membrane. Both sides of the extended impervious membrane are $0.5 \mathrm{~m}$, as shown in Figure 2. The improved bioretention can cause rainwater infiltration without affecting the regular operation of roads. The optimized structure effectively achieves the unity of sponge facility functionality and surrounding road safety; due to the different water-sensitive characteristics of loess with varying grades of collapsibility, the soil wetting deformation characteristics and water infiltration have different effects on the site [28]. Therefore, the influence of rainwater infiltration of partial anti-seepage bioretention in loess sites with different collapsibility can verify the applicability of this structure form in various collapsibility sites, and it is necessary to provide support for its further application. 


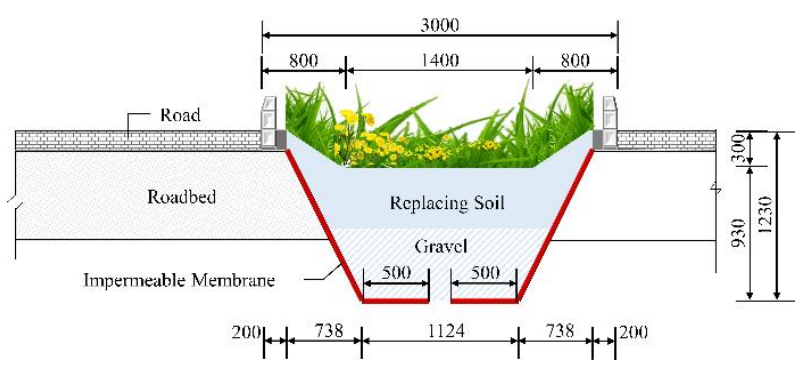

Figure 2. Schematic diagram of the partial anti-seepage bioretention in the loess area.

In summary, the research is mainly for the runoff regulation, rainwater prevention and control function of sponge facilities, and the water infiltration law of a single loess site at present. Rarely studies the infiltration influence of sponge facilities in the loess site. To fill the above gaps, based on the partial anti-seepage bioretention in the collapsible loess area shown in Figure 2, this paper studies the influence of concentrated infiltration of rainwater near municipal road facilities on the seepage field and deformation field of the site according to the characteristics of different collapsible loess sites and proposes an optimization scheme of bioretention facilities under different site conditions. In addition, the full-scale immersion test is used to verify the rationality of the numerical model applied to the infiltration effect of bioretention facilities near municipal roads in the typical collapsible loess field. To explore the applicability of the various kinds of typical sponge facilities under the collapsible loess sites and to optimize the facilities' risk prevention and control measures is of positive significance to the scientific safety of the sponge city construction under such geological conditions.

\section{Field Test and Numerical Verification}

\subsection{Field Test}

The collapsible loess site in Chang'an District, Xi'an City, Shaanxi Province, was selected, and a full-scale immersion test of bioretention near municipal roads was carried out on the site. The location and stratigraphic distribution of the test site as shown in Figure 3. The site size was $25 \mathrm{~m} \times 12 \mathrm{~m}$, and the soil parameters of the site are shown in Table 2. The soil parameters in the facility were the same as those in reference [27].

This experiment mainly consists of a bioretention system, water supply system, and test system. The site layout is shown in Figure 4a. The bioretention system consists of a $14 \mathrm{~m}$ long bioretention facility belt and $14 \mathrm{~m} \times 3.5 \mathrm{~m}$ compacted loess, which is simulated municipal roads. The water supply system consists of a reservoir $(5 \mathrm{~m} \times 3 \mathrm{~m} \times 1 \mathrm{~m})$, measuring weir and return channel. In the experiment, the water in the reservoir is pumped to the measuring weir for water supply. An open channel is set at the end of the bioretention facility belt to form a flow loop with the reservoir. The test system is mainly composed of a moisture sensor and data collector. The moisture sensor is CS635 made by Campbell company of USA, and its precision is $0 \pm 1 \%$. Twelve sensors were buried at $1.5 \mathrm{~m}, 2 \mathrm{~m}, 2.5 \mathrm{~m}$, and $3 \mathrm{~m}$ by exploratory well excavation (Figure $4 \mathrm{~b}$ ). The data collector model was TDS-602, and the fastest sampling speed reached $0.02 \mathrm{~s}$.

In the field test, the most unfavorable rainfall was simulated with a constant water head of $20 \mathrm{~cm}$ for $24 \mathrm{~h}$ to observe the change in site water content.

The results show that the water content of the loess site where the bioretention facilities are located changes with time during water infiltration, as shown in Figure 5. 


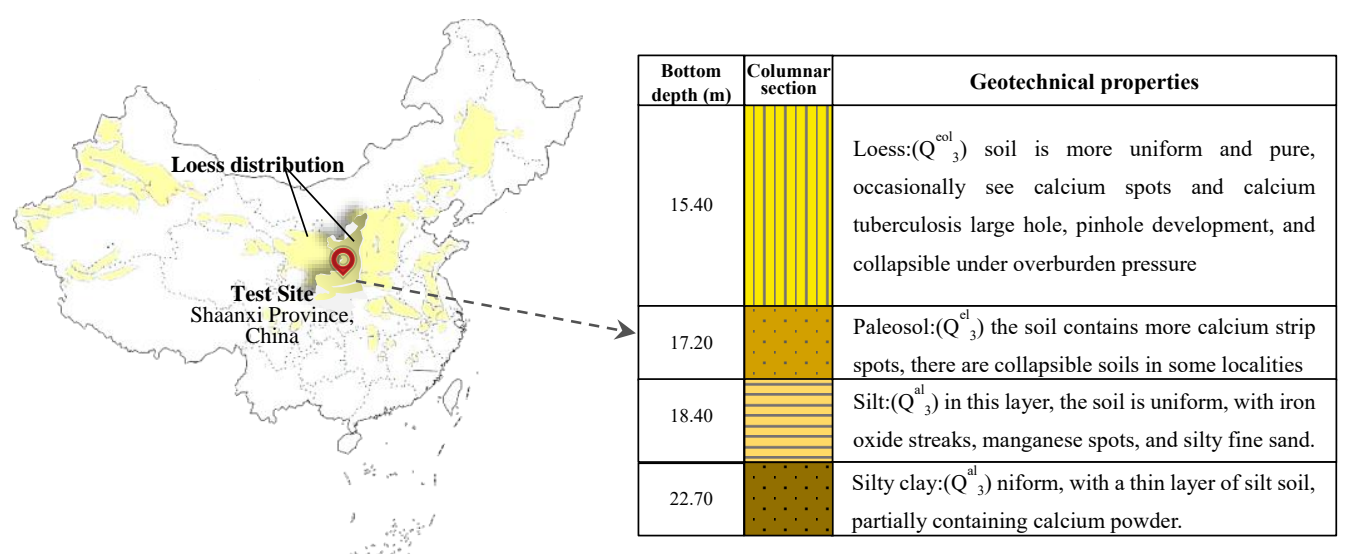

Figure 3. The location and stratigraphic distribution of the test site.

Table 2. Soil parameters of test site.

\begin{tabular}{cc}
\hline Soil Layer & Loess \\
\hline Thickness of layer $/ \mathrm{m}$ & 4.50 \\
Density $\left(\mathrm{kg} / \mathrm{m}^{3}\right)$ & 1.50 \\
Initial water content $(\%)$ & 17.9 \\
Saturated water content $(\%)$ & 0.42 \\
Permeability coefficient $/ \mathrm{m}^{-1}$ & $4.458 \times 10^{-7}$ \\
Internal friction angle ${ }^{\circ}$ & 24 \\
Cohesion $/ \mathrm{kPa}$ & 30 \\
Collapsibility coefficient & 0.8 \\
Compression modulus $/ \mathrm{MPa}$ & 7.2 \\
\hline
\end{tabular}

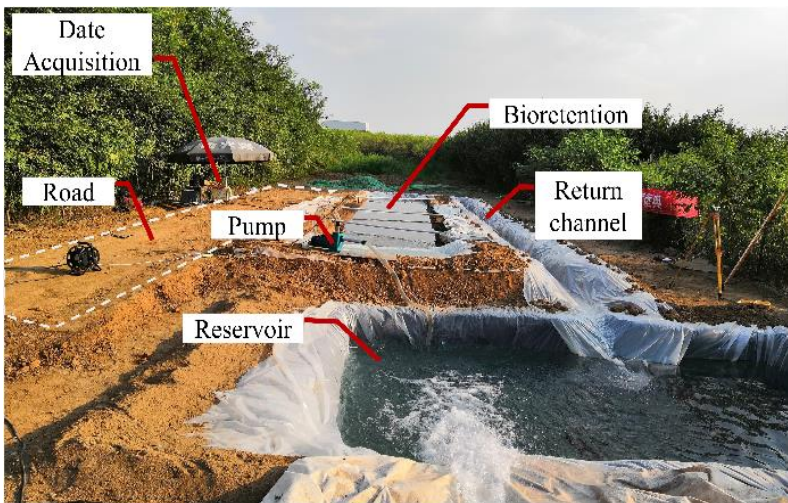

(a)

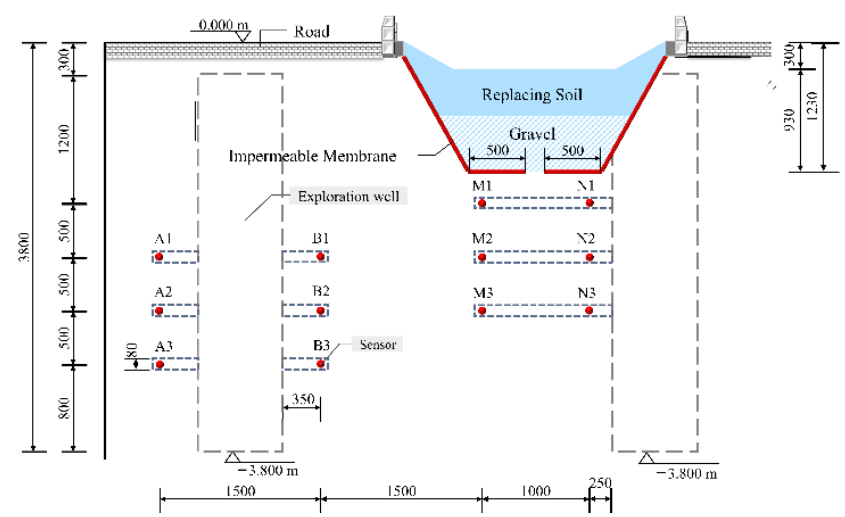

(b)

Figure 4. Site layout with the field test: (a) site layout, (b) sensor layout of test section (mm).

It can be seen from the figure that:

(1) The site water content at $\mathrm{M}$ and $\mathrm{N}$ at the bottom of the facility basically remains unchanged at the initial stage of infiltration. With increasing infiltration time, the water content increases sharply and tends to be stable gradually so that the whole infiltration process can be divided into three stages: (I) initial stability, (II) rapid growth, and (III) slow growth. (a) The duration of stage I are approximately $0.5 \mathrm{~h}, 1 \mathrm{~h}$, and $2.5 \mathrm{~h}$ at depths of $1.5 \mathrm{~m}, 2 \mathrm{~m}$, and $2.5 \mathrm{~m}$, respectively. The duration is different at different depths, and the duration increases with increasing infiltration depth. The duration of non-subgrade side $\mathrm{N}$ is longer than that of subgrade side $\mathrm{M}$. The reason for the above phenomenon may be that the layout process of facilities impacts the foundation field, thus affecting the law of water permeability. (b) With the increase in infiltration depth, the duration of stage II increases, but the increment of water content decreases. For example, on the right side of the facility 
bottom, it takes approximately $3.5 \mathrm{~h}$ for the water content increment at $1.5 \mathrm{~m}$ to reach the maximum value of $38 \%$, while it takes approximately $5.5 \mathrm{~h}$ for the water content increment at $2 \mathrm{~m}$ to reach the maximum value of $35 \%$; (c) In stage III, the maximum stable water content decreases with the increase in depth, it can apply that the stable water content at the depth of $1.5 \mathrm{~m}, 2 \mathrm{~m}$, and $2.5 \mathrm{~m}$ decreases in turn. This phenomenon is because the porosity of soil decreases with increasing depth, the saturated water content of soil decreases, and the stable water content decreases.

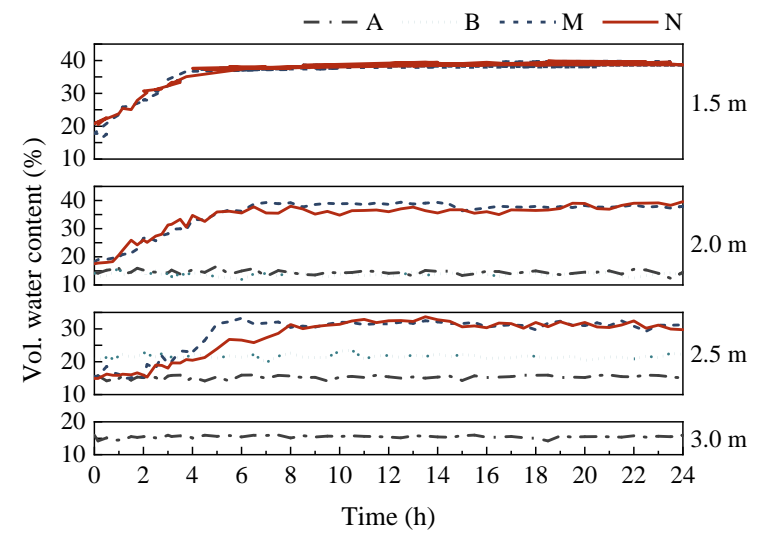

Figure 5. Variation curve of water content with time at different positions.

(2) The maximum water content in the process of infiltration for $24 \mathrm{~h}$ was $\theta_{\max }=39.8 \%$ $<$ average saturated water content of the site $\theta_{\text {Sat }}=42 \%$, that is to say, the concentrated infiltration process of facility rainwater in loess site belongs to unsaturated infiltration state. Similar experimental results have been obtained from the study of the loess water infiltration law in Reference [17].

(3) The volume water content of soil at positions A and B at the bottom of the subgrade fluctuates slightly with increasing infiltration time, basically maintaining the initial water content $\pm 2 \%$. It can be demonstrated that the influence of facility water infiltration on the seepage field of the subgrade is small.

\subsection{Numerical Model for the Field Test}

GeoStudio2007 software SEEP/W module was used to establish the finite element model based on the field test site conditions and test groups. The physical properties of the model soil layer are the same as the field test conditions. The geometry, boundary conditions, and material types of the numerical model are shown in Figure 6. Horizontal constraints are imposed on both sides of the foundation, horizontal, and vertical constraints are imposed on the bottom, and a free boundary is taken for the upper structure. According to the most unfavorable condition, the rainfall boundary is calculated, which is $20 \mathrm{~cm}$ water accumulation in the upper part of the detention zone lasting for $24 \mathrm{~h}$. The impermeable interface material is used to simulate the impermeable membrane, and the permeability coefficient is set as 0 .

The volume water content changes with time at W1, W2, and W3 are calculated and compared with the measured results at M1, M2, and B2, as shown in Figure 7.

The water content of soil at $\mathrm{W} 1$ and $\mathrm{W} 2$ reaches saturation at $3 \mathrm{~h}$ and $4.5 \mathrm{~h}$, respectively. The saturated water content is slightly higher than the measured value, and the initial water content is slightly lower than the measured value. The above phenomenon may be caused by neglecting the heterogeneity of soil and making the initial moisture content of all parts of the site $16 \%$, which lead to the rapid stage have some difference between the two methods, to the duration of the rapid water content stage, the numerical model has more effective change than field test measured date. On the other hand, the overall change trend of the water content calculated by the numerical models at each position is consistent with that of the field. For W1 and W2, the water content increases slowly-sharply-gradually 
stable. In contrast, for W3, the water content remains stable with time, and the concentrated infiltration of facility water has little effect on the water content of the subgrade within $24 \mathrm{~h}$. Additionally, the stable value of water content in each location directly impacts the surrounding roads than the time-varying process of water content. The stable value of the water content in the numerical simulation test results is slightly larger than that in the field measurement results. Therefore, it is effective to use a numerical model to analyze the influence of water infiltration in facilities.

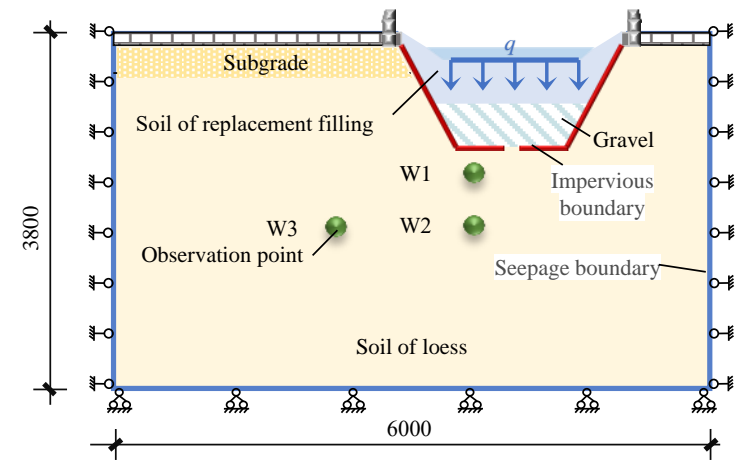

Figure 6. Schematic diagram of the geometric model for the numerical model.

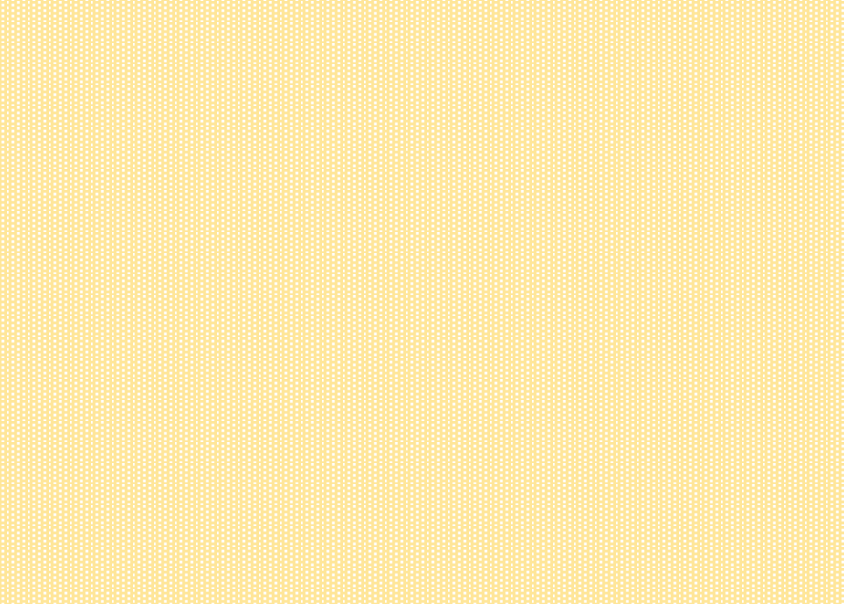

Figure 7. Comparison curve of the volume water content at different positions with different methods.

\section{Numerical Analysis of the Infiltration Effect in the Different Collapsible \\ Loess Fields}

\subsection{Stratigraphic Conditions and Finite Element Model}

The Xixian new area is a concentrated construction area of sponge cities in the collapsible loess area of China. The section form of a typical municipal road in this area (Figure 8) is selected as the engineering background. The road is in the form of four roads. The $3 \mathrm{~m}$ wide biological detention facility is located between the $16 \mathrm{~m}$ wide motorway and the $8 \mathrm{~m}$ wide auxiliary road.

One side of the road was selected, and GeoStudio (2007) was used to establish the finite element model, as shown in Figure 9. The foundation soil is homogeneous loess with different collapsibility grades. The calculation depth is $10 \mathrm{~m}$ from the road surface downward, and the widths of the motorway and the auxiliary road are $16 \mathrm{~m}$ and $8 \mathrm{~m}$, respectively, on both sides. The cross slope of the motorway and the auxiliary road is $1.5 \%$. Unstructured quadrilateral and triangular meshes are used in the mesh generation of the model. 


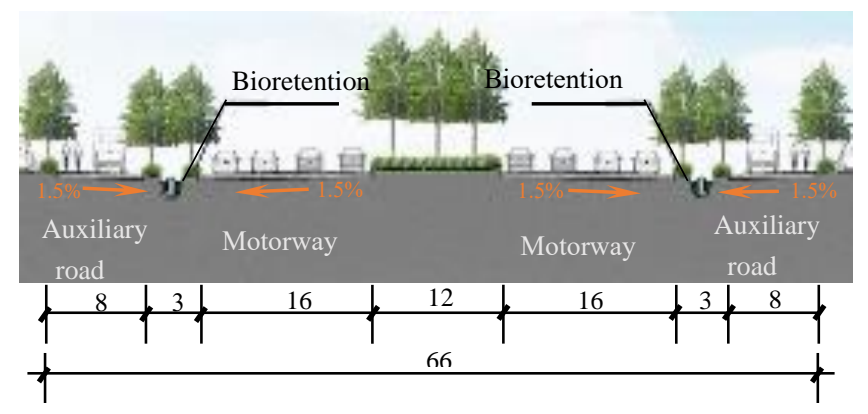

Figure 8. Section of a typical municipal road in a collapsible loess area of China.

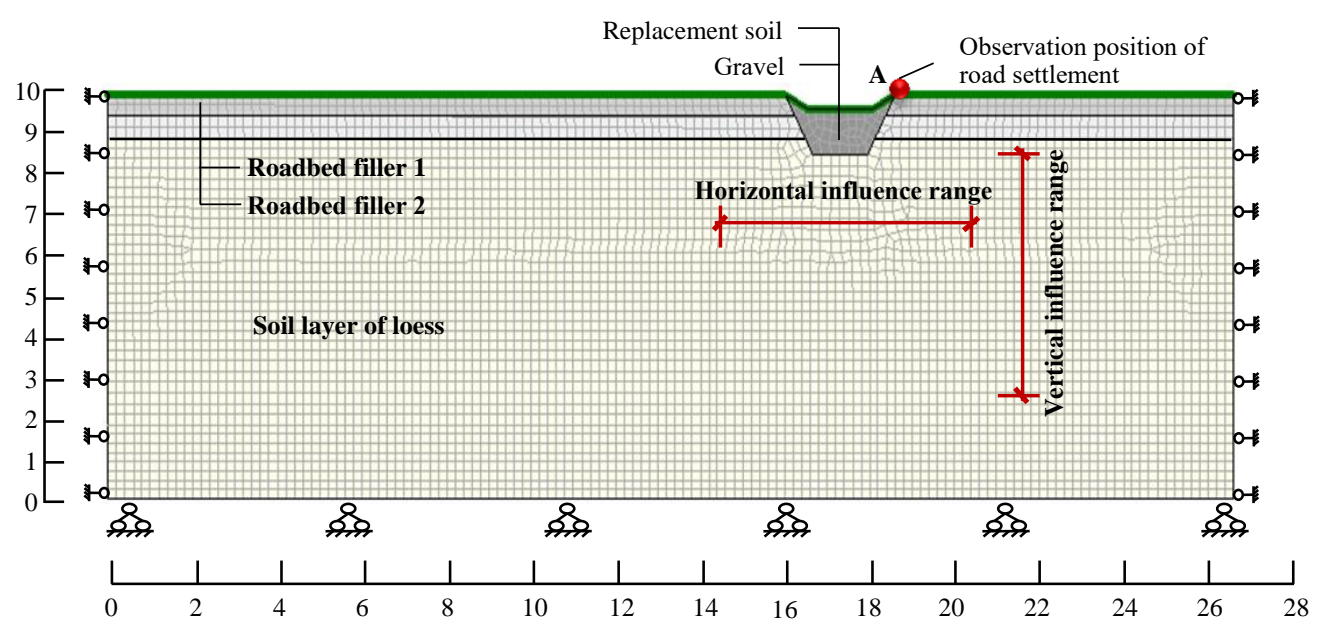

Figure 9. Finite element model.

To analyze the influence of water infiltration on the site water content and road settlement under different conditions, the specific calculation steps of the model are as follows: First, the SEEP/W module in the software is used to analyze the transient state of the model, and the pore water pressure under the initial condition is obtained; then, the initial pore water pressure is imported into the Intitu module of SIGMA/W to calculate the initial stress; next, taking the initial pore water pressure and initial stress as the initial conditions of the following coupling analysis, the coupling of the seepage field and stress field is calculated. In this way, fluid-solid semi-coupling analysis is carried out, and each step is taken as the parent of the next step. The variation rules of displacement and pore water pressure under different time steps are obtained. The scope of water content change is calculated from the bottom of the facilities; the observation position of road settlement change is selected from the nearest point A to the facilities.

\subsection{Material Parameters}

In China's central and western regions, such as Gansu, Shanxi, and Shaanxi, loess is relatively developed, and the distribution of loess collapsibility is uneven. To improve the universality of sponge construction in the loess area, it is necessary to select representative collapsible loess sites with collapsible I, II, and III for research. According to the literature [29], the physical parameters of the soil are shown in Table 3, and the mechanical parameters of the road surface material and subgrade filler are the same as those in the literature [27]. 
Table 3. Mechanical parameters of different collapsible loess.

\begin{tabular}{cccc}
\hline Collapsibility Grade & III & II & I \\
\hline Thickness of soil layer $/ \mathrm{m}$ & 7.3 & 7.3 & 7.3 \\
Soil weight $/ \mathrm{kN} \cdot \mathrm{m}^{-3}$ & 14.97 & 16.12 & 17.78 \\
Saturated water content/\% & 55 & 51 & 45 \\
Void ratio & 1.20 & 1.01 & 0.85 \\
Cohesion $/ \mathrm{kPa}$ & 27 & 35 & 47 \\
Internal friction angle $/\left(^{\circ}\right)$ & 21.5 & 22.6 & 23.1 \\
Compressibility factor $/ \mathrm{MPa}^{-1}$ & 4.8 & 9.7 & 6.8 \\
Saturated permeability coefficient $/(\mathrm{m} / \mathrm{s})$ & $1.11 \times 10^{-4}$ & $0.45 \times 10^{-5}$ & $6.12 \times 10^{-5}$ \\
Collapsibility coefficient & 0.08 & 0.04 & $0.02-0.03$ \\
\hline
\end{tabular}

\subsection{Hydraulic Parameter}

According to the existing soil parameters, the VG model shown in Equations (1) and (2) are used to predict the SWCC curve and permeability coefficient curve, as shown in Figure 10.

$$
\begin{gathered}
\theta_{w}=\theta_{r}+\frac{\theta_{s}-\theta_{r}}{\left[1+(a \psi)^{n}\right]^{m}} \\
k_{w}=k_{s} \frac{\left[1-(a \psi)^{n-1}\left(1+\left((a \psi)^{n}\right)^{-m}\right]\right.}{\left[1+(a \psi)^{n}\right]^{\frac{m}{2}}}
\end{gathered}
$$

where $\theta_{w}$ is the volumetric water content, $\theta_{r}$ is the residual volumetric water content, $\theta_{s}$ is the saturated volumetric water content, $\psi$ is the matric suction, $\mathrm{a}, \mathrm{m}$ and $\mathrm{n}$ are fitting parameters with $\mathrm{m}=1-1 / \mathrm{n}, k_{w}$ is the permeability coefficient at matric suction $\psi$, and $k_{s}$ is the saturated coefficient of permeability.

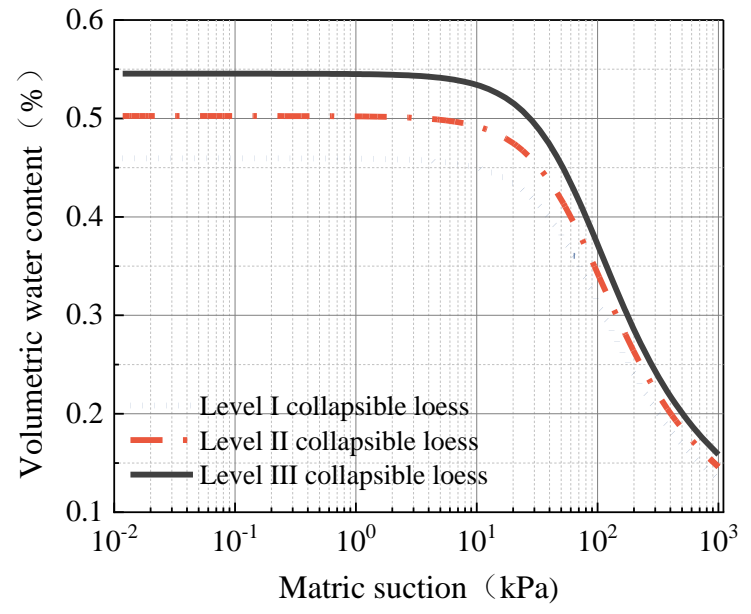

(a)

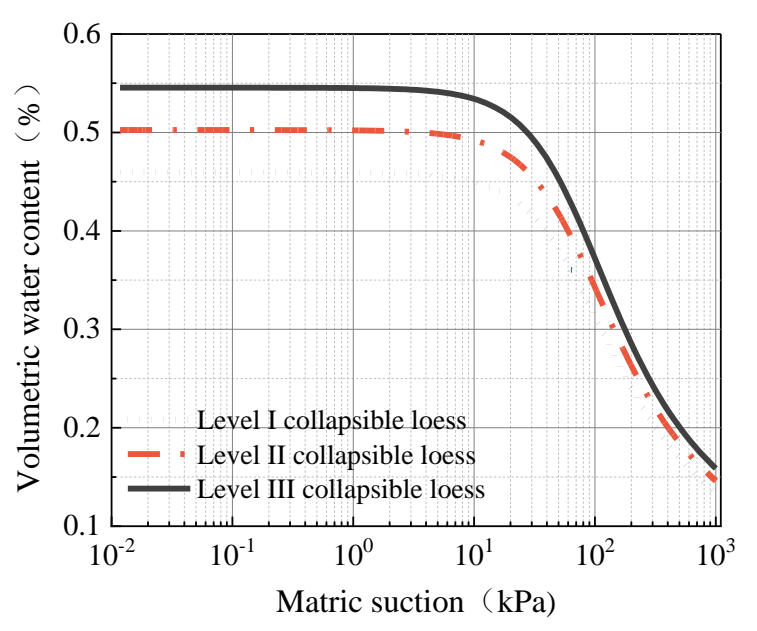

(b)

Figure 10. The hydraulic characteristic curve (a) SWCC curve; (b) permeability coefficient curve.

\subsection{Boundary Condition}

Combined with engineering practice, the boundary conditions are set as follows: (1) horizontal displacement constraint and free drainage of the left and right boundaries;

(2) horizontal and vertical displacement constraints + free drainage at the bottom boundary; and (3) technical guidelines for the construction of sponge cities in China (2014). When the ponding time at the top of the bioretention exceeds $24 \mathrm{~h}$, the water is drained through the seepage well. Based on a certain safety reserve, this study selected a ponding height at the top of the bioretention layer of $20 \mathrm{~cm}$ for $72 \mathrm{~h}$, and the remaining seepage boundary was the free permeable boundary. 


\section{Numerical Model Results and Discussion}

\subsection{Influence Range of Rainwater Infiltration}

The seepage range of bioretention in different collapsible loess sites under the action of rainfall is shown in Figure 11. "I-1" in the figure indicates the influence range of seepage when the water accumulated in the upper part of the bioretention of the class I collapsible loess site lasts for one day, I-3 indicates the seepage influence range of the upper part of the biological retention facilities in the class I collapsible loess site when the ponding lasts for 3 days, and the other labels are the same.

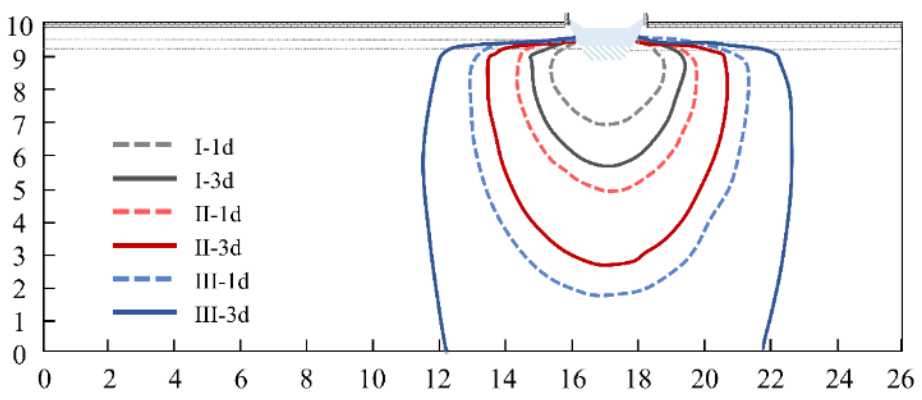

Figure 11. Influence range of infiltration in different collapsible loess sites.

According to the diagram, it can be seen:

(a) For the same collapsible grade, the seepage influence range increases with the infiltration time. The infiltration influence range of class I - III site at $3 \mathrm{~d}$ is more incredible than at $1 \mathrm{~d}$. With the extension of infiltration time, the diffusion velocity in the influence range of seepage decreases. At the same time, the water diffusion rate of the site with facilities is faster than that of the site without facilities. For example, for the class II collapsible loess site, according to the literature [30], it takes 5 days when the water reaches $5 \mathrm{~m}$, while it takes only 1 day for sites with sponge facilities. The above phenomenon may be that the planting soil and gravel layer inside the sponge facility increase the water residence time, raise the infiltration head, and accelerate the water infiltration rate. Therefore, it is necessary to fully consider the influence of the site when arranging sponge facilities in collapsible loess site;

(b) For bioretention on different grades of collapsible loess sites, under a specific infiltration time, the influence range of seepage increases significantly with the increase in collapsible grade. For the class I collapsibility, when the ponding time lasts for one day, the maximum influence width of seepage in the foundation soil is $3.5 \mathrm{~m}$ at the bottom of the detention facility. The maximum influence depth is $2.1 \mathrm{~m}$. However, the maximum influence width and depth of class III collapsible loess fields are $8.4 \mathrm{~m}$ and $7.1 \mathrm{~m}$, respectively. The reason for the above phenomenon may be that the higher the collapsibility level, the greater the saturated permeability coefficient of the site, and the water diffusion increases with the increase in collapsibility level;

(c) With the increase in infiltration time, the diffusion speed of water in the site gradually decreases. The higher the collapsibility grade, the slower the reduction speed, and the horizontal diffusion speed are less than the vertical diffusion speed. The shape of water diffusion is slender. The maximum influence depth of class I collapsible field with 3 days of ponding time is $1.1 \mathrm{~m}$ higher than that with 1 day of ponding time. The maximum influence depth of class II collapsible site increases by $2.2 \mathrm{~m}$. The cause of this phenomenon may be related to loess as a typical specific unsaturated soil with a smaller horizontal permeability coefficient than the vertical permeability coefficient.

\subsection{Road Settlement Caused by Rainfall Infiltration}

The curve of road settlement with the time of different collapsibility loess sites under the action of rainfall is shown in Figure 12. It can be seen from the figure that: 


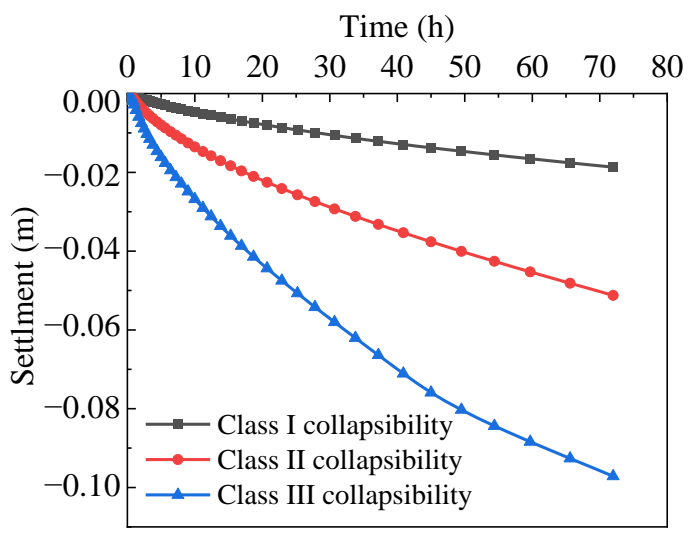

Figure 12. Settlement versus time curve at different collapsible loess sites.

(a) Pavement settlement increases with the increase in ponding time, and its growth rate gradually slows down with time. That is, for all kinds of sites, the subgrade has prominent settlement at the initial stage of infiltration, and the change of subgrade settlement gradually decreases with the increase in ponding time;

(b) The collapsibility grade of the site has a significant impact on the site settlement. Under the same ponding conditions, the higher the collapsibility grade, the greater the site's settlement after immersion. When the ponding lasts for 3 days, the maximum pavement settlement is $18.6 \mathrm{~mm}, 51.2 \mathrm{~mm}$, and $97.1 \mathrm{~mm}$ for class I to III collapsible loess sites, respectively;

(c) The slope of settlement increases with the increase in collapsibility grade. That is, the higher the collapsibility grade, the faster the settlement increases. The above phenomenon is mainly caused by the comprehensive action of saturated permeability coefficient, compression modulus, and gravity of the site. The greater the collapsibility, the more efficiently the soil strength is affected by water [18].

In conclusion, the road settlement caused by rainfall infiltration of bioretention on class II and class III collapsible loess sites is far more than that of class I collapsible sites, and the settlement is greater than the settlement standard in the code for design of highway subgrade of China (JTGD30-2015), which is $40 \mathrm{~mm}$. In order to avoid the impact of rainwater infiltration of sponge facilities on nearby municipal roads, the typical facility structure can be adopted for low-grade collapsible loess sites. It is recommended for high-grade collapsible loess sites to shorten the maximum water storage time of facilities and the seepage prevention measures of facilities should be strengthened.

\section{Optimization Anti-Seepage Design of Bioretention}

According to Liang (2019), increasing the extension length of impervious membranes can only reduce the seepage effect and pavement settlement to a small extent. Therefore, for the loess sites with collapsibility classes II and III, the foundation soil in a certain range is replaced to reduce the influence of seepage in the bioretention on the foundation soil and pavement settlement. The applicability of the optimized bioretention facilities in all kinds of collapsible loess sites can be improved.

To achieve the above objective, the elastic modulus of the in situ foundation soil should be appropriately increased, and the deformation modulus $E_{\mathrm{s}}$ of the replacement soil should be selected as $10 \mathrm{MPa}$, which can be converted into the compressibility of the soil $\alpha$ $14 \mathrm{MPa}^{-1}$. The saturated permeability coefficient $K_{\mathrm{S}}$ is $6 \times 10^{-7} \mathrm{~m} / \mathrm{s}$. With the width of the bottom of facilities is $1.2 \mathrm{~m}$ and the facility width at the second subgrade location is approximately $1.7 \mathrm{~m}$, the convenience of actual construction was considered, a rectangular area is selected under the detention facilities for replacement, as shown in Figure 13. The working conditions $a \times b$ were chosen: $1.7 \mathrm{~m} \times 0.4 \mathrm{~m}, 1.7 \mathrm{~m} \times 0.5 \mathrm{~m}, 2.0 \mathrm{~m} \times 0.4 \mathrm{~m}, 2.0 \mathrm{~m} \times 0.5 \mathrm{~m}$. 


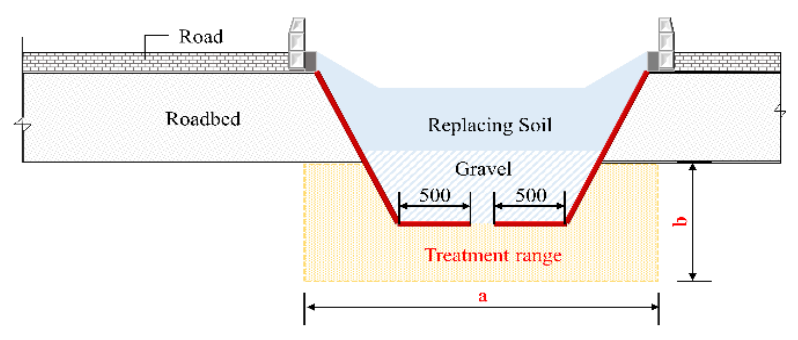

Figure 13. Schematic diagram of the foundation treatment range of bioretention.

The influence range of seepage under different conditions is shown in Figures 14 and 15. The underground foundation replacement of class II and class III collapsible sites significantly impacts the range of rainwater infiltration. The range of rainfall infiltration decreases with the increase in the area of the replacement soil layer under bioretention. To Figures 14 and 15, it can be seen from Figures 14a,b and 15a,b that increasing the depth range $b$ of foundation treatment can effectively reduce the influence range of vertical and horizontal water infiltration and the area with significant water content in the foundation, and then reduce the range of collapse caused by collapsible deformation in the site; Meanwhile, under the same infiltration time and replacement width a, the soil saturation inside the facility increases with the increase in the depth $b$. So the rise in the replacement depth is more conducive to the water storage capacity of the facility. Comparing Figures $14 \mathrm{a}, \mathrm{c}$ and $15 \mathrm{a}, \mathrm{c}$, it is found that only increasing the width of the foundation treatment has little effect on the seepage range. The above phenomenon may be due to the diffusion form of water in the loess foundation field mainly affected by vertical diffusion. The larger the compaction range along the vertical direction is, the more conducive it is to alleviate the influence of water seepage in the foundation soil.
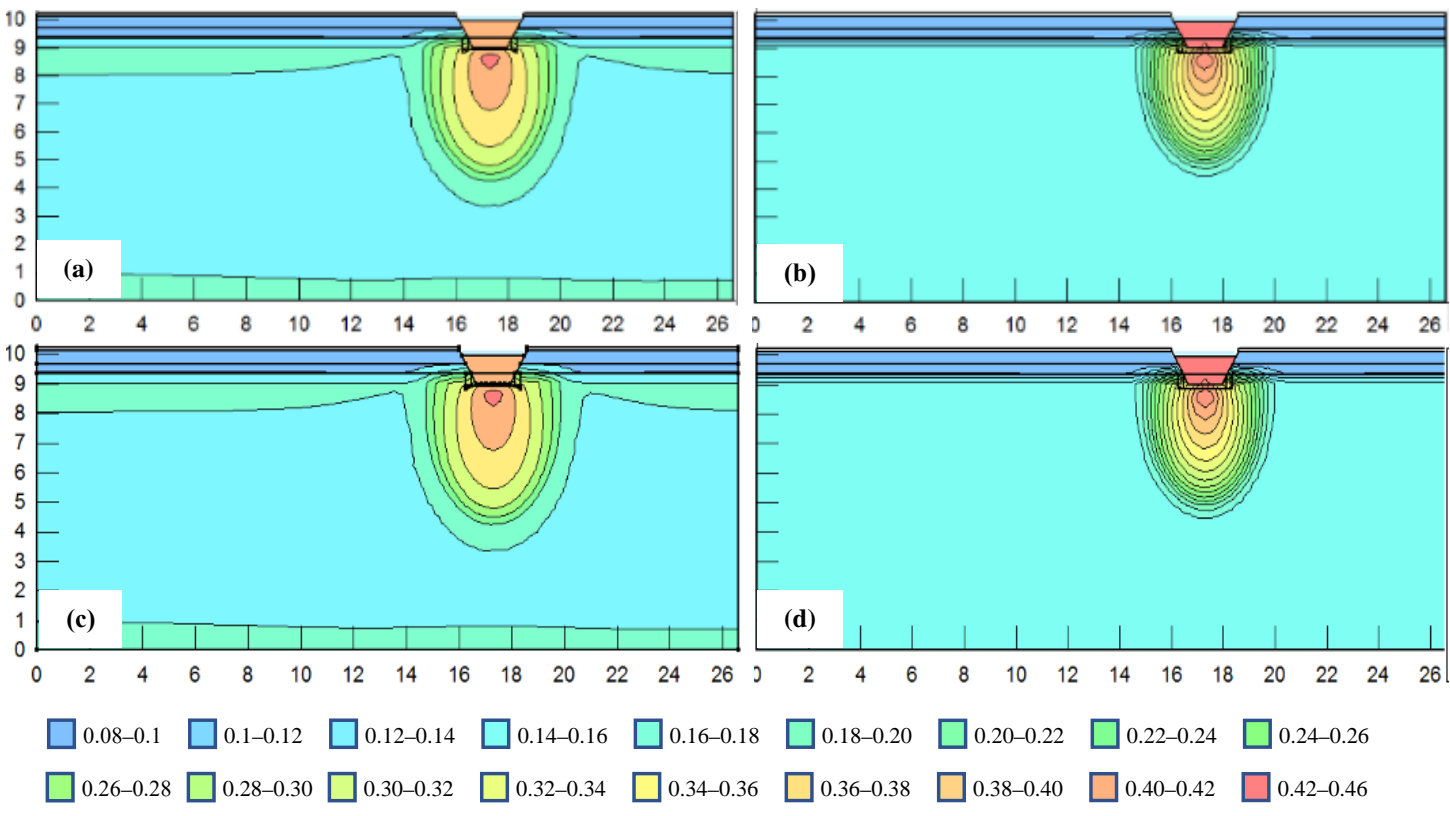

Figure 14. Influence range of seepage in different foundation treatment ranges of class II collapsible sites: (a) $1.7 \mathrm{~m} \times 0.4 \mathrm{~m}$; (b) $1.7 \mathrm{~m} \times 0.5 \mathrm{~m}$; (c) $2.0 \mathrm{~m} \times 0.4 \mathrm{~m}$; (d) $2.0 \mathrm{~m} \times 0.5 \mathrm{~m}$. 

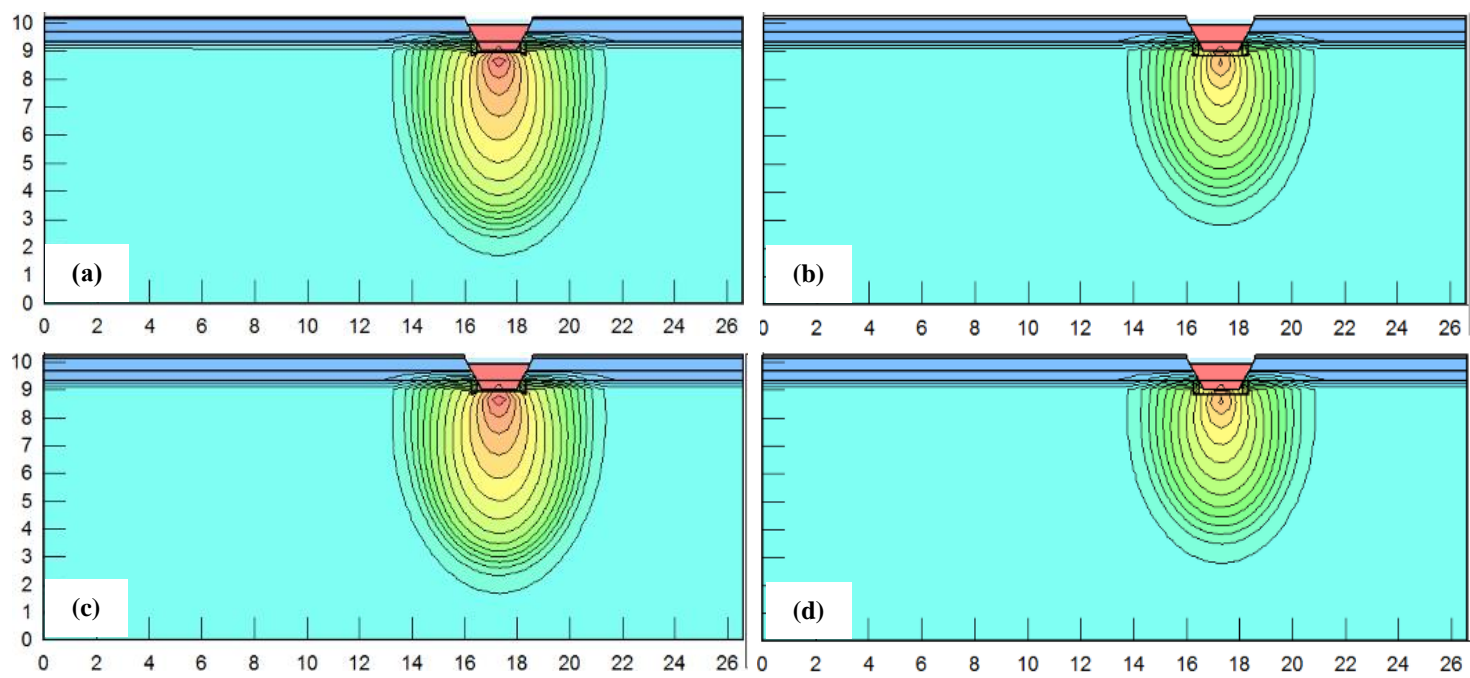

$\square 0.08-0.1 \quad \square 0.1-0.12 \quad \square 0.12-0.14 \quad \square 0.14-0.16 \quad \square 0.16-0$.
$\square 0.26-0.28 \square 0.28-0.30 \square 0.30-0.32 \quad \square 0.32-0.34 \quad \square 0.34-0.36$

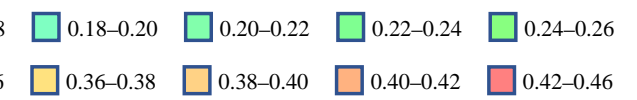

Figure 15. Influence range of seepage in different foundation treatment ranges of class III collapsible sites: $(\mathbf{a}) 1.7 \mathrm{~m} \times 0.4 \mathrm{~m}$; (b) $1.7 \mathrm{~m} \times 0.5 \mathrm{~m}$; (c) $2.0 \mathrm{~m} \times 0.4 \mathrm{~m}$; (d) $2.0 \mathrm{~m} \times 0.5 \mathrm{~m}$

The curve of road settlement with the time of each collapsible loess site under different foundation treatment ranges is shown in Figure 16. Under the same seepage conditions, different foundation treatment ranges have a more significant impact on road settlement. The larger the foundation treatment range is, the smaller the settlement under the same conditions. For the class II collapsible loess site, the road settlement is less than $40 \mathrm{~mm}$ under all working conditions. However, for the class III collapsible loess site, when the foundation treatment depth $b=0.40 \mathrm{~m}$, the road settlement exceeds the allowable value of $40 \mathrm{~mm}$. When the treatment depth increases to $b=0.50 \mathrm{~m}$, the settlement meets the specification limit. When the foundation treatment range is $1.7 \mathrm{~m} \times 0.5 \mathrm{~m}$ and $2.0 \mathrm{~m} \times 0.5 \mathrm{~m}$, the settlement caused by rainwater infiltration is similar under the same conditions, and the road settlement law is similar when the foundation treatment range is $1.7 \mathrm{~m} \times 0.4 \mathrm{~m}$ and $2.0 \mathrm{~m} \times 0.4 \mathrm{~m}$. The increase in foundation treatment width a has little influence on the pavement settlement, while the increase in foundation treatment depth $b$ has a noticeable impact on the pavement settlement under the same conditions.

Time (h)

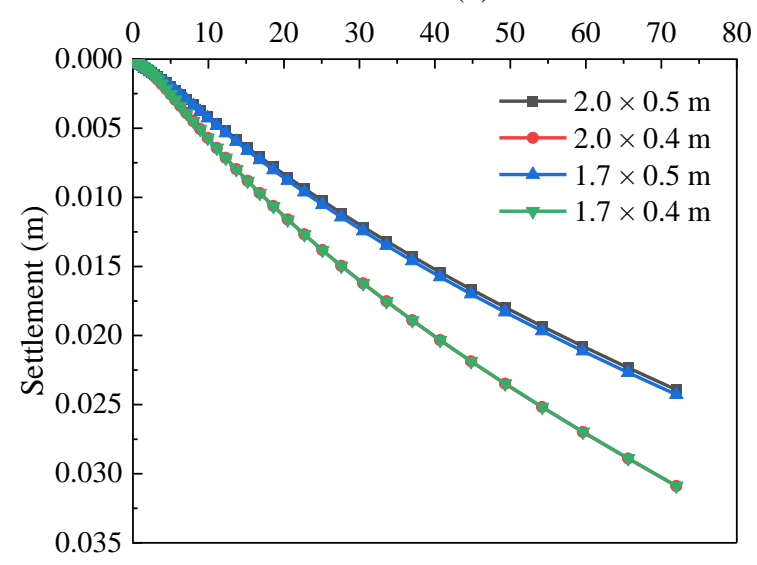

(a)

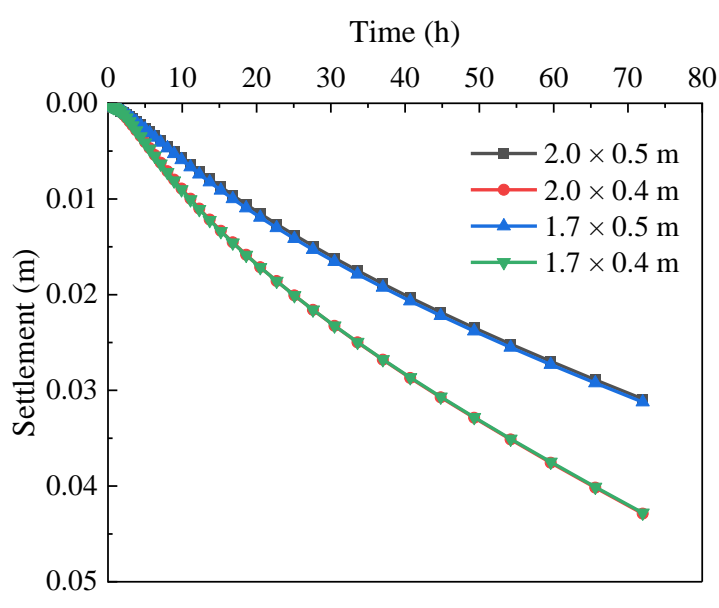

(b)

Figure 16. The curve of pavement settlement with time under different foundation treatment ranges in different loess sites: (a) class II collapsibility, (b) class III collapsibility. 
Under actual conditions, to ensure the safety of the surrounding roads when bioretention is built in the site with high collapsibility and to ensure the function of the facilities, partial anti-seepage bioretention facilities can be used in class I collapsible loess fields directly. For class II and class III collapsible loess sites, the anti-seepage membrane can be arranged at the side and bottom of the facilities, and the soil under bioretention can be compacted or replaced to control the compressibility of the soil $\alpha \leq 0.14$ Then, considering a certain safety reserve, it can dig down $0.5 \mathrm{~m}$ vertically along the edge of the second layer of the subgrade, replace the foundation soil according to the requirements, and then slope the facilities.

\section{Conclusions}

To ensure the functionality of typical bioretention in collapsible loess areas and the safety of surrounding municipal roads, the general rules of rainwater infiltration of the partial anti-seepage bioretention facilities near municipal roads in different collapsible loess fields are discussed, and relevant suggestions for facility optimization are put forward. Additionally, the validity of the model used to analyze the law of water infiltration under this condition is verified, and the results are as follows:

(1) With increasing infiltration time, the water content at the bottom of the partial anti-seepage bioretention can be divided into three stages: initial stability, rapid growth, and slow growth. When the water time at the top of the facility is less than $24 \mathrm{~h}$, the rainfall concentrated infiltration has little impact on the municipal roads around the facility;

(2) The collapsible grade of the loess site has an important influence on the rainwater seepage of sponge facilities on adjacent roads. When the collapsible grade of the site is the same, the seepage influence range increases with the infiltration time; The influence range of seepage of the partial anti-seepage bioretention facilities near municipal roads increases with the increase in collapsibility class. At the same time, the sensitivity of infiltration range to infiltration time also increases with the rise of collapsibility class;

(3) The pavement settlement increases with the increase in water accumulation time, and its growth rate gradually slows down with time. The collapsibility grade of the site has a significant impact on the site settlement. Under the same ponding conditions, the higher the collapsibility grade, the greater the site's settlement after immersion;

(4) Bioretention facilities with partial anti-seepage control can be used in various collapsible loess fields. For different types of collapsible sites, when the foundation soil of partial anti-seepage sloping infiltration bioretention is the grade I collapsible loess, base replacement should not be carried out. When the foundation soil is class II and III collapsible loess, a $1.7 \mathrm{~m} \times 0.5 \mathrm{~m}$ area at the bottom of the facility can be selected for foundation treatment and can shorten the maximum water storage time of facilities.

Author Contributions: Writing-original draft preparation, X.W.; methodology, X.Z., S.C.; software, X.L.; validation, X.W., X.Z., and X.L.; writing-review and editing, Z.H., Y.J.; project administration, Z.H.; funding acquisition, Z.H., Y.J. All authors have read and agreed to the published version of the manuscript.

Funding: This research is funded by the National Natural Science Foundation of China (Grant No. 41877285, 41472267) and the Research Funds of Management Committee of Fengxi New City in Xixian New Area (Grant No. 214028170390).

Institutional Review Board Statement: Not applicable.

Informed Consent Statement: Not applicable.

Data Availability Statement: The datasets supporting the results of this article are included within the article and its additional files.

Acknowledgments: This study was jointly supported by the National Natural Science Foundation of China (Grant No. 41877285, 41472267) and the Research Funds of Management Committee of Fengxi New City in Xixian New Area (Grant No. 214028170390). We thank Xinbo Lv, Nannan Chen and 
Jiakuang Ma for their assistance during the field experiment. And the authors are very grateful to the anonymous reviewers and editors for their very useful comments and suggestions.

Conflicts of Interest: The authors declare no conflict of interest.

\section{References}

1. $\mathrm{Wu}$, J.; Yang, R.; Song, J. Effectiveness of low-impact development for urban inundation risk mitigation under different scenarios: A case study in Shenzhen, China. Nat. Hazards Earth Syst. Sci. 2018, 18, 2525-2536. [CrossRef]

2. Yke, C.; Warren, M.P.; Johnson, T.; LaGro, J.; Scharfenberg, J.; Groth, P.; Freed, R.; Schroeer, W.; Main, E. Assessment of low impact development for managing stormwater with changing precipitation due to climate change. Landsc. Urban Plan. 2011, 103, 166-173. [CrossRef]

3. Li, Q.; Wang, F.; Yu, Y.; Huang, Z.; Li, M.; Guan, Y. Comprehensive performance evaluation of LID practices for the sponge city construction: A case study in Guangxi, China. J. Environ. Manag. 2019, 231, 10-20. [CrossRef] [PubMed]

4. Ahiablame, L.; Shakya, R. Modeling flood reduction effects of low impact development at a watershed scale. J. Environ. Manag. 2016, 171, 81-91. [CrossRef]

5. Hu, M.; Sayama, T.; Zhang, X.; Tanaka, K.; Takara, K.; Yang, H. Evaluation of low impact development approach for mitigating flood inundation at a watershed scale in China. J. Environ. Manag. 2017, 193, 430-438. [CrossRef] [PubMed]

6. Hu, P.; Ma, Y.; Xue, H.; Zhang, F. Application of low impact development technology in rainwater drainage system reconstruction project. Clust. Comput. 2017, 22, 533-543. [CrossRef]

7. Chen, G.; Meng, X.; Qiao, L.; Zhang, Y.; Wang, S. Response of a loess landslide to rainfall: Observations from a field artificial rainfall experiment in Bailong River Basin, China. Landslides 2017, 15, 895-911. [CrossRef]

8. Kozubal, J.; Steshenko, D. The complex compaction method of an unstable loess substrate. Arab. J. Geosci. 2014, 8, 6189-6198. [CrossRef]

9. Yates, K.; Fenton, C.; Bell, D. A review of the geotechnical characteristics of loess and loess-derived soils from Canterbury, South Island, New Zealand. Eng. Geol. 2018, 236, 11-21. [CrossRef]

10. Assadi-Langroudi, A. A conceptual model for loess in England: Principles and applications. Proc. Geol. Assoc. 2019, 130, 115-125. [CrossRef]

11. DeBusk, K.M.; Wynn, T.M. Storm-Water Bioretention for Runoff Quality and Quantity Mitigation. J. Environ. Eng. 2011, 137, 800-808. [CrossRef]

12. Hou, J.; Han, H.; Qi, W.; Guo, K.; Li, Z.; Hinkelmann, R. Experimental investigation for impacts of rain storms and terrain slopes on low impact development effect in an idealized urban catchment. J. Hydrol. 2019, 579, 124176. [CrossRef]

13. Xu, H.; Lyu, W. Research on Application of Grassed Swales on Control of Urban Rainfall and Runoff. Pearl River 2019, 40, 97-100.

14. Yekkalar, M.; Haselbach, L.; Langfitt, Q. Impacts of a Pervious Concrete Retention System on Neighboring Clay Soils. J. Cold Reg. Eng. 2018, 32, 04017023. [CrossRef]

15. Tang, S.; Luo, W.; Jia, Z.; Liu, W.; Li, S.; Wu, Y. Evaluating Retention Capacity of Infiltration Rain Gardens and Their Potential Effect on Urban Stormwater Management in the Sub-Humid Loess Region of China. Water Resour. Manag. 2015, 30, 983-1000. [CrossRef]

16. Chen, L.-M.; Chen, J.-W.; Chen, T.-H.; Lecher, T.; Davidson, P.C. Measurement of Permeability and Comparison of Pavements. Water 2019, 11, 444. [CrossRef]

17. Huang, X.; Zhang, G.; Yao, Z.; Zhang, J. Research on deformation, permeability regularity and foundation treatment method of dead-weight collapse loess with heavy section. Rock Soil Mech. 2011, 32, 100-108. [CrossRef]

18. Wu, X.P.; Wang, L.M.; Fang, J.H.; Xu, A.H.; Zhou, Y.L.; Zhao, Y.H. Seepage characteristics and their relationship with self-weight collapse of intact loess ground. Chin. J. Geotech. Eng. 2018, 040, 1002-1010. [CrossRef]

19. Tu, X.; Kwong, A.; Dai, F.; Tham, L.; Min, H. Field monitoring of rainfall infiltration in a loess slope and analysis of failure mechanism of rainfall-induced landslides. Eng. Geol. 2009, 105, 134-150. [CrossRef]

20. Zhang, M.; Li, T. Triggering Factors and Forming Mechanism of Loess Landslides. J. Eng. Geol. 2011, 19, 530-541. (In Chinese) [CrossRef]

21. Liu, H.; Ni, W.; Yang, H.; Yan, B. Site Test on Infiltration of Loess Subgrade under Rainfall Circumstance. J. Earth Sci. Environ. 2008, 1, 60-63. [CrossRef]

22. Li, P.; Li, T.; Vanapalli, S.K. Influence of environmental factors on the wetting front depth: A case study in the Loess Plateau. Eng. Geol. 2016, 214, 1-10. [CrossRef]

23. Zhang, L. Path of Sponge City Construction in Northwestern China: An Empirical Study on Xixian New Area. City Plan Rev. 2016, 40, 108-112. [CrossRef]

24. Si, J.; Kong, Q.; Ning, Z. Study on Construction Scheme of Sponge City for Municipal Roads in Jinghe New Town. Urban Roads Bridg. Flood Control 2018, 8, 195-214. [CrossRef]

25. D'Aniello, A.; Cimorelli, L.; Cozzolino, L.; Pianese, D. The Effect of Geological Heterogeneity and Groundwater Table Depth on the Hydraulic Performance of Stormwater Infiltration Facilities. Water Resour. Manag. 2019, 33, 1147-1166. [CrossRef]

26. D'Aniello, A.; Cimorelli, L.; Cozzolino, L. The Influence of Soil Stochastic Heterogeneity and Facility Dimensions on Stormwater Infiltration Facilities Performance. Water Resour. Manag. 2019, 33, 2399-2415. [CrossRef] 
27. Liang, H.; Li, X.; Zhang, X.; Ma, Y.; Ji, G. Optimization Analysis of Rainwater Infiltration in Bioretention Zone near Municipal Roads. China Water Wastewater 2020, 36, 107-112. [CrossRef]

28. Xie, W.-L.; Li, P.; Vanapalli, S.K.; Wang, J.-D. Prediction of the wetting-induced collapse behaviour using the soil-water characteristic curve. J. Asian Earth Sci. 2018, 151, 259-268. [CrossRef]

29. Chai, S.; Hu, Z.; Wang, C.; Ma, Y.; Ji, G. Influences of Rain Water Infiltration on Adjacent Building Base in Sponge Cities. J. Guilin Univ. Technol. 2019, 39, 635-642. [CrossRef]

30. Meng, X.; Liao, H.; Zhang, J. Infiltration Law of Water in Undisturbed Loess and Backfill. Water 2020, 12, 2388. [CrossRef] 